\title{
Carbon and nitrogen distribution pattern in soil profile cultivated with Eucalyptus
}

\author{
Charlote Wink ${ }^{1}$ (D), Dalvan José Reinert ${ }^{2}$ (D), Jean Paolo Gomes Minella ${ }^{2}$ (D) \\ ${ }^{1}$ Universidade Federal do Mato Grosso (UFMT), Sinop, MT, Brasil \\ ${ }^{2}$ Universidade Federal de Santa Maria (UFSM), Santa Maria, RS, Brasil
}

\begin{abstract}
The objective of this study was to evaluate the distribution pattern of total organic carbon (TOC) and total nitrogen (TN) in the native field soil profile and Eucalyptus sp. The study was carried out in native field and in eucalyptus plantations with 20,44, 180 and 240 months, located in Santa Maria and Manoel Viana, RS, Brazil. The decay rate $(\mathrm{k})$ of the TOC and TN contents up to $1.2 \mathrm{~m}$ depth was determined by the graphical, numerical and mathematical method using the third order negative exponential model. The content of TOC and TN deep in the soil showed a third order negative exponential distribution. However, the methods used to estimate the decay rate generate differences in TOC and TN contents along the soil profile.
\end{abstract}

Keywords: soil profile, organic matter, forest plantations. 


\section{INTRODUCTION AND OBJECTIVES}

The dynamics of carbon and nitrogen in Eucalyptus plantations linked to the depth distribution pattern it is not well described and is still uncertain. According to Harrison et al. (2011), studies involving this subject are developed down to $0.2 \mathrm{~m}$, due to the importance of this layer and the difficulty in deep sampling. Rumpel \& Kögel-Knabner (2011) point out that carbon in the subsoil is as important as that of the surface due to its greater long-term stability, its lower concentration and its non-saturation in the subsurface horizons. It is estimated that the soil under pasture stores $615 \mathrm{Gt}$ of carbon down to $0.2 \mathrm{~m}$ and $2344 \mathrm{Gt}$ of carbon down to $3 \mathrm{~m}$, and the residence time in depth increases considerably (Fontaine et al., 2007).

The average value of the soil carbon inventory in the Brazilian soils is $39 \mathrm{Pg}$ down to $0.3 \mathrm{~m}$ and $105 \mathrm{Pg}$ down to $2.0 \mathrm{~m}$ (Carvalho et al., 2010). As result of the biomass addition, the carbon distribution in the soil profile decreases exponentially from surface to subsurface (Meersmans et al., 2009; Santruckova et al., 2010). In forest plantations, it is important to correlate the root growth with the carbon distribution in depth, compared to the species with growth and superficial root distribution. According to Boddey et al. (2010), soils under agricultural cultivation show a tendency to decrease the carbon content with increasing depth. However, the land use and soil management, type and depth of soil preparation and incorporation or removal of residues from native vegetation may influence this content.

The first mathematical description of the carbon and nitrogen distribution in forest soil profile used an exponential equation down to $0.2-0.3 \mathrm{~m}$ depth with hyperbolic distribution mathematical model (Nakane \& Shinozaki, 1978). In the last decades, the most of scientific contribution in the description of these processes occurred by the use of negative exponential model (Bernoux et al., 1998; Elzein \& Balesdent, 1995; Meersmans et al., 2009; Rosenbloom et al., 2006). This model has been applied in the studies of Mestdagh et al. (2004) and Minasny et al. (2006), as well as in the proposition to integrate these to simulation models (Hilinski, 2001). Among several benefits, the author highlights the possibility of determining the carbon stock in layers intervals. However, among the disadvantages, we highlight the influence of the soil density causing the increase of the stock below the depth used in the simulation.

The climate, soil type and plant species influence the adjustment of this model, which is especially important and complex when involving soils under forest. This model is also relevant to describe the ability of the methods to adjust itself to soils cultivated with eucalyptus plantations, as well as to obtain the quality in the estimation of these contents. Therefore, the objective of the study is to evaluate the distribution pattern of total organic carbon (TOC) and total nitrogen (TN) in the native grassland soil profile and Eucalyptus sp. by different methods considering the third order negative exponential model.

\section{MATERIALS AND METHODS}

The study was carried out in two contrasting land use commonly used in Southern Brazil: native grassland and Eucalyptus sp. plantations. The soils profiles are located in the municipalities of Santa Maria $\left(29^{\circ} 30^{\prime} \mathrm{S}\right.$ and $\left.54^{\circ} 15^{\prime} \mathrm{W}\right)$ and Manoel Viana (29 $34^{\prime} \mathrm{S}$ and $\left.55^{\circ} 35^{\prime} \mathrm{W}\right)$. The region presents an annual average temperature of $19{ }^{\circ} \mathrm{C}$ and annual precipitation from 1,300 to $1,800 \mathrm{~mm}$ (Moreno, 1961). In Santa Maria, the soils are classified as Hapludalf (Soil Survey Staff, 1999) and the land use studied was native grassland $\left(\mathrm{CN}_{\mathrm{SM}}\right)$ and plantations of Eucalyptus saligna Smith with 20 months (Euc20) and Eucalyptus grandis Hill ex Maiden with 44 months. The percentage of coarse sand, fine sand, silt and clay was, respectively, 21.0, 37.6, 18.1 and 23.3 for soil under $\mathrm{CN}_{\mathrm{SM}} ; 23.2,31.0$, 18.7 and 27.1 for soil under Euc20; and 22.5, 32.0, 17.0 and 28.5 for soil under Euc44. In Manoel Viana, the soils classified as Hapludalf (Soil Survey Staff, $1999)$ were studied under native grassland $\left(\mathrm{CN}_{\mathrm{MV}}\right)$, and 180 months-old (Euc180) and 240 months-old (Euc240) specimens of Eucalyptus sp. were analyzed. The percentage of coarse sand, fine sand, silt and clay was, respectively, 8.8, 46.2, 21.9 and 23.1 for soil under Euc180; 6.4, 47.2, 17.4 and 29.0 for soil under Euc240; and 5.8, 49.1, 16.5 and 28.6 for soil under $\mathrm{CN}_{\mathrm{MV}}$.

The Euc20 (0.72 ha) plantation was located in flat field and the implantation consisted of mechanical mowing and ants combat. Soil tillage before planting consisted of one operation with chisel plow with inclined shanks followed by one harrowing leveler (disk "off-set" or in "V" shape). The Euc44 (0.225 ha) 
plantation, situated on top of a relief, was mechanically mowed and area and soil preparation were tilled with a tractor-mounted rotary hoe (only in the planting line) to a $0.15 \mathrm{~m}$ depth. The planting of the Eucalyptus seedlings was carried out in spaces of $3 \times 2$ and $3 \times 1.5 \mathrm{~m}$, respectively, in Euc20 and Euc44, with later (when needed) mowing in the interline. Both plantations have not received fertilization, nor thinning or pruning. Next to these plantations, as a reference, the native grassland $\left(\mathrm{CN}_{\mathrm{SM}}\right)$ was evaluated, which did not receive any type of management (Wink, 2009). The Euc180 and Euc2 40 plantations were planted on minimum soil preparation, respectively at $2 \times 1$ and $3 \times 2 \mathrm{~m}$ spacing, without fertilization but having already received thinning interventions. The native grassland $\left(\mathrm{CN}_{\mathrm{MV}}\right)$ next to these plantations received beef cattle continuous grazing (Rosa, 2010).

In each treatment, four soil profiles were sampled in six soil layers, corresponding to the average depths of $1.28 \mathrm{~m}$ (Euc20), $1.21 \mathrm{~m}$ (Euc44), $1.16 \mathrm{~m}\left(\mathrm{CN}_{\mathrm{SM}}\right)$ according to Wink (2013) and 1,5 $\mathrm{m}$ (Euc180, Euc240 and $\mathrm{CN}_{\mathrm{MV}}$ ) according to Rosa (2010). The samples were air-dried, crushed, sieved in a $2 \mathrm{~mm}$ mesh, milled in agate gravel and analyzed for TOC and TN in the EA1112 Flash Elementary Autoanalyzer.

In order to study the distribution of TOC and TN in the soil profile, the percentages of these were adjusted for standard soil layers $(0.0-0.1,0.1-0.2,0.2-0.4,0.4-$ $0.6,0.6-0.8,0.8-1.0$ and $1.0-1.2 \mathrm{~m})$. Then the content $\left(\mathrm{g} \mathrm{cm}^{-3}\right)$ of TOC and TN was calculated, considering the soil density of the respective native grassland of each site (Rosa, 2010; Wink, 2013).

The distribution pattern of the TOC and TN content in the profile was evaluated by means of the graphical method, in which the curve fit considered the third order mathematical model (Equation 1). The coefficient $b$ represent the decay rate of the curve, that is, similar to the parameter $\mathrm{k}$ proposed by HILINSKI (2001). The $\mathrm{R}_{\text {aj }}^{2}$ and the significance of the coefficient $\mathrm{b}$ evaluated the quality of the fit.

$\mathrm{Y}=\mathrm{Y}_{0}+\mathrm{a}^{*} \mathrm{e}^{\left(-\mathrm{b}^{*} \mathrm{x}\right)}$

Where Y: TOC or TN content (\% or $\mathrm{g} \mathrm{cm}^{-3}$ ); $\mathrm{x}$ : cumulative mean depth $(0.05,0.15,0.3,0.5,0.7,0.9,1.1 \mathrm{~m}) ; \mathrm{Y} 0$, a, b: parameters of the models. The coefficient $b$ represent the decay rate of the curve that is similar to the parameter k proposed by Hilinski (2001).

The distribution of the TOC and TN was simulated by the mathematical and the numerical method, both using the model of Bernoux et al. (1998) and Rosenbloom (1997), also performed from the definition of constant $\mathrm{k}$ (Hilinski, 2001). For this, the values of the unknowns of the model were defined considering the maximum content in the surface $(\mathrm{C} 0)$, the minimum content recorded in the last layer of the evaluated profile $(\mathrm{Cb})$ and the sum of the content of these elements in depth $(\mathrm{Cz})$. In the numerical method, this sum represented the accumulated mean depths $(\mathrm{z}=0.05,0.15,0.3,0.5$, $0.7,0.9,1.1 \mathrm{~m})$, on the other side, for mathematical method, the accumulated sum was related to mean total depth $(\mathrm{z}=1.1 \mathrm{~m})$ in the profile. The numerical model determined the $k$ value of the equation using the Marquardt method. This method defines possible solutions of $\mathrm{k}$, from an interactive process of estimation of a numerical solution which minimizes the sum of squares of the error. The mathematical model determined the value of $\mathrm{k}$ by simple calculation using the Equation 1 in Excel $^{\circledR}$ software.

The values of $k$ estimated by the graphical and numerical method were compared to those observed by the mathematical method through the analysis of lack of adjustment (LOFIT), with the significance of the $\mathrm{F}$ test and the square root of error (RQEM) evaluation at a level of $95 \%$ confidence interval (Smith et al., 1997). The values of $k$ obtained by the mathematical method in each site were evaluated by analysis of variance and, if significant, the means were compared by the Tukey test at the level of $5 \%$ of error. The estimated content of TOC and TN with different values of $k$ was evaluated by the T-test paired with dependent samples at $5 \%$ error level.

\section{RESULTS AND DISCUSSION}

The native grassland and the eucalyptus plantations, considering a $\mathrm{R}_{\text {aj }}^{2}$ value higher than 0.7 and a significant b coefficient at $5 \%$ error level (Figure 1), had $64 \%$ and $90 \%$ of the profiles with a tendency to the negative exponential distribution in depth for the content (\%) of TOC and TN, respectively. Only the TOC (\%) presented profiles with $\mathrm{R}_{\mathrm{aj}}^{2}$ values less than 0.5 . Consequently, the other profiles obtained $\mathrm{R}_{\text {aj }}{ }^{\text {v }}$ values between 0.5 and 0.7 in the evaluation of TOC and TN content.

Plantations of Eucalyptus sp. of different ages in Southern Brazil also showed a decrease in carbon accumulation down to $1 \mathrm{~m}$ depth (Schumacher \& Witschoreck, 2004). 
The differences of trend of the distribution curves of TOC and TN on native grassland and Eucalyptus plantations soil profile are attributed to the particularities of the soil, in relation to the physical, chemical and biological conditioning factors of the transformation or translocation of organic matter by the movement of edaphic fauna. These differences may also be associated with the type of vegetation or crop, as well as the history of local use. The vegetation is related to the contribution of aerial or root material, constituent of the organic matter. This is the type of root system which can explore different soil horizons, the renewal intensity of the fine root biomass that contribute to the increase of the organic material incorporated in depth, as well as the direct influence of the age of the trees, the dynamics of deposition and decomposition biomass, modifying the organic matter, carbon and nitrogen contents in the soil.

According to Jobbágy and Jackson (2000), the distribution of carbon in the soil profile occurs due to a decrease in the renewal of organic carbon in depth, root renewal, organic carbon movement along the profile and vertical movement of soil organisms.
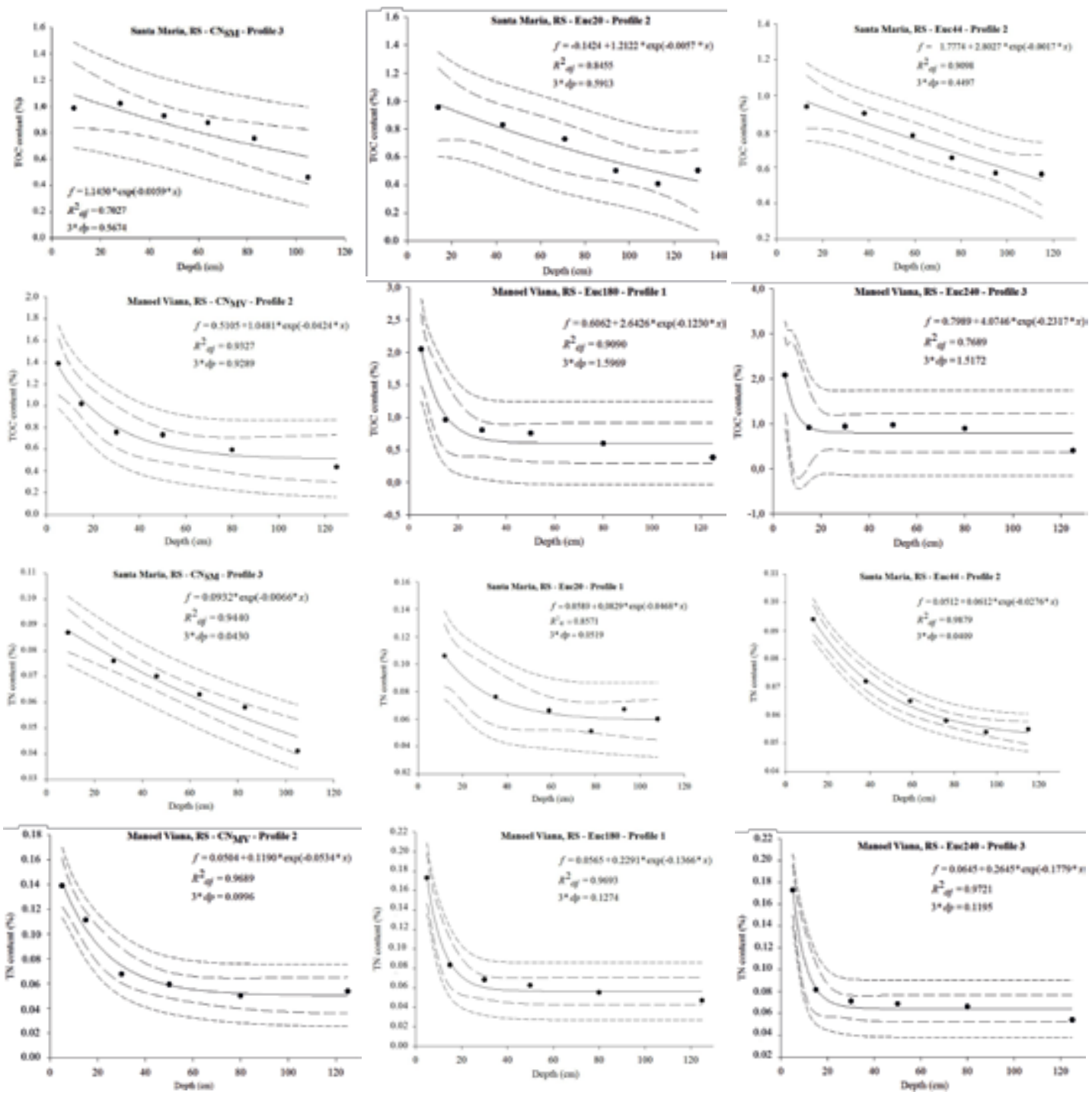

Figure 1. General distribution pattern (\%) of total organic carbon (TOC) and total nitrogen (TN) in the native grassland and Eucalyptus plantations. 
For Rumpel and Kögel-Knabner (2011), the input of organic material in the subsoil occurs by the mechanisms of root exudation, depending on the type of vegetation by flow of dissolved organic matter and by pedoturbation, since the earthworms can move down to five meters deep. In some soil types, depending on the climate, soil processes and use, the entry of this material can occur by the translocation of particles of organic material and transport of clay bound to the organic matter. Studies such as Charnay et al. (2005) indicate that the microbial activity is significant at $2.5 \mathrm{~m}$ depth, that is, below the rooting zone.

The carbon decomposition in depth is associated with the development of microbial activity, such as oxygen depletion or fresh carbon shortage originated from plant residues (Fontaine et al., 2007). For Rumpel \& Kögel-Knabner (2011), the oxygen limitation in subsurface horizons may be responsible for the long carbon turnover time. For Torn et al. (1997), this decrease is more accentuated to $0.2-0.3 \mathrm{~m}$, unlike Mikhailova et al. (2000), for whom the decrease was most pronounced down to $1.2-1.3 \mathrm{~m}$ after 50 years of fallow, with 38 to $43 \%$ of this loss occurring down to $0.1 \mathrm{~m}$ layer. For these same authors, in the cultivated land the significant changes of the organic carbon in the soil occur down to $0.7-0.8 \mathrm{~m}$.

The land use and soil management influences significantly the decrease of carbon at the surface and subsurface layers (Meersmans et al., 2009), even though in depth there is a lower concentration of carbon reflecting (Rumpel \& Kögel-Knabner, 2011) and thus in significant differences along the soil profile (Santruckova et al., 2010).

\subsection{Parameterization of the decay rate $(k)$}

Considering the mathematical method, among the different soil uses, the decay rate for the TOC content varied by $0.0082 \%$ and $0.0075 \mathrm{~g} \mathrm{~cm}^{-3}$, and for the $\mathrm{TN}$ content, the decay rate over the profile varied by $0.0058 \%$ and $0.0051 \mathrm{~g} \mathrm{~cm}^{-3}$ (Table 1 ). In most of all land uses, the $\mathrm{k}$ mean values of Eucalyptus plantations are higher than the values of $k$ in their respective native grassland in the different methods.

The decay rate $(\mathrm{k})$ of the TOC and TN content in the different land uses by the mathematical method did not present significant difference by the $\mathrm{F}$ test of the analysis of variance.
Table 1. Average decay rate (k) of total organic carbon (TOC) and total nitrogen (TN) determined by different methods.

\begin{tabular}{|c|c|c|c|c|}
\hline \multicolumn{5}{|c|}{$\begin{array}{c}\text { Average decay rate }(\mathrm{k}) \text { determined } \\
\text { by the Mathematical Method }\end{array}$} \\
\hline $\begin{array}{l}\text { Land } \\
\text { use }\end{array}$ & $\begin{array}{l}\text { TOC } \\
(\%)\end{array}$ & $\begin{array}{c}\text { TOC } \\
\left(\mathrm{g} \mathrm{cm}^{-3}\right)\end{array}$ & $\begin{array}{l}\text { TN } \\
(\%)\end{array}$ & $\begin{array}{c}\text { TN } \\
\left(\mathrm{g} \mathrm{cm}^{-3}\right)\end{array}$ \\
\hline Euc20 & -0.0212 & -0.0211 & -0.0186 & -0.0185 \\
\hline Euc44 & -0.0235 & -0.0234 & -0.0204 & -0.0203 \\
\hline $\mathrm{CN}_{\mathrm{SM}}$ & -0.0186 & -0.0186 & -0.0200 & -0.0199 \\
\hline Euc180 & -0.0160 & -0.0167 & -0.0162 & -0.0170 \\
\hline Euc240 & -0.0166 & -0.0173 & -0.0173 & -0.0182 \\
\hline $\mathrm{CN}_{\mathrm{MV}}$ & -0.0153 & -0.0159 & -0.0146 & -0.0152 \\
\hline \multicolumn{5}{|c|}{$\begin{array}{c}\text { Average decay rate }(\mathbf{k}) \text { determined } \\
\text { by Numerical Method }\end{array}$} \\
\hline $\begin{array}{l}\text { Land } \\
\text { use }\end{array}$ & $\begin{array}{l}\text { TOC } \\
(\%)\end{array}$ & $\begin{array}{c}\text { TOC } \\
\left(\mathrm{g} \mathrm{cm}^{-3}\right)\end{array}$ & $\begin{array}{l}\text { TN } \\
(\%)\end{array}$ & $\begin{array}{c}\mathrm{TN} \\
\left(\mathrm{g} \mathrm{cm}^{-3}\right)\end{array}$ \\
\hline Euc20 & -0.0233 & -0.0233 & -0.0210 & -0.0214 \\
\hline Euc44 & -0.0242 & -0.0242 & -0.0225 & -0.0225 \\
\hline $\mathrm{CN}_{\mathrm{SM}}$ & -0.0219 & -0.0219 & -0.0218 & -0.0219 \\
\hline Euc180 & -0.0162 & -0.0168 & -0.0169 & -0.0179 \\
\hline Euc240 & -0.0181 & -0.0189 & -0.0178 & -0.0184 \\
\hline $\mathrm{CN}_{\mathrm{MV}}$ & -0.0180 & -0.0187 & -0.0170 & -0.0178 \\
\hline \multicolumn{5}{|c|}{$\begin{array}{c}\text { Average decay rate }(\mathrm{k}) \text { determined } \\
\text { by the Graphical Method }\end{array}$} \\
\hline $\begin{array}{l}\text { Land } \\
\text { use }\end{array}$ & $\begin{array}{c}\text { TOC } \\
(\%)\end{array}$ & $\begin{array}{c}\text { TOC } \\
\left(\mathrm{g} \mathrm{cm}^{-3}\right)\end{array}$ & $\begin{array}{l}\text { TN } \\
(\%)\end{array}$ & $\begin{array}{c}\mathrm{TN} \\
\left(\mathrm{g} \mathrm{cm}^{-3}\right)\end{array}$ \\
\hline Euc20 & -0.0180 & -0.0161 & -0.0374 & -0.0355 \\
\hline Euc44 & -0.0047 & -0.0029 & -0.0293 & -0.0274 \\
\hline $\mathrm{CN}_{\mathrm{SM}}$ & -0.0149 & -0.0137 & -0.0256 & -0.0241 \\
\hline Euc180 & -0.0471 & -0.0431 & -0.0936 & -0.0971 \\
\hline Euc240 & -0.0690 & -0.0683 & -0.1253 & -0.1370 \\
\hline $\mathrm{CN}_{\mathrm{MV}}$ & -0.0465 & -0.0433 & -0.0674 & -0.0664 \\
\hline
\end{tabular}

* estimated values of $\mathrm{k}$ by the numerical method were significant at the level of $<0.0001$.

In the numerical method between the different land uses, the $\mathrm{k}$ variation for the TOC content was $0.008 \%$ and $0.0074 \mathrm{~g} \mathrm{~cm}^{-3}$, and for the NT content, this variation was $0.0056 \%$ and $0.0047 \mathrm{~g} \mathrm{~cm}^{-3}$ (Table 1). These values are similar to the values obtained by the mathematical method, as well as to the values found by Mestdagh et al. (2004) in sandy soil, using the 
same negative exponential model of carbon content distribution in depth.

Considering the graphical method, between different soil uses the decay rate $(\mathrm{k})$ of the TOC content varied by $0.0643 \%$ and $0.0654 \mathrm{~g} \mathrm{~cm}^{-3}$ and, for the $\mathrm{TN}$, the variation of the $\mathrm{k}$ of the content was by $0.0997 \%$ and $0.1129 \mathrm{~g} \mathrm{~cm}^{-3}$. These values of $\mathrm{k}$ are similar to those reported by Mestdagh et al. (2004) in different soils, confirming that the value of the parameter $\mathrm{k}$ is important when we intend to make extrapolations of the carbon content in depth.

Therefore, in the evaluated soil profiles it was possible to find a numerical solution to the unknowns of the model, representing the contents of carbon and nitrogen in depth. Indirectly, this already describes the tendency of negative exponential distribution for these in-depth contents, confirmed later by the adjustment of the curve by the graphical method, reaffirming the possibility of the equation proposed by Hilinski (2001) to be applied in simulation models.

The higher decay rate in the soil profiles of Eucalyptus plantations is associated with the natural tendency of formation and accumulation of organic material from the litterfall, and the intense density of fine roots at the soil surface, consequently influencing the surface content of these elements (Gatto et al., 2010; Wink, 2009). However, this distribution of soil organic carbon along the profile can not only be determined by the distribution of roots as a function of vegetation and landscape, but also be influenced by precipitation, leaching (Wang et al., 2010), type and pedogenetic processes. The effect of climate, especially precipitation and temperature influencing the distribution of carbon content in depth, is also confirmed by Jobbágy \& Jackson (2000). Precipitation influences the type of vegetation and temperature and has an effect on the decomposition of the residue. The percolation of carbon in subsurface and the enrichment of it in depth can be provided by the movement and translocation of the community of organisms in the soil.

The higher the decay rate, the greater the decrease of this estimated content along the soil profile. This estimated content along the soil profile may be infinitely small, tending to zero as the depth analyzed increased, but in fact will never be zero, since the negative exponential distribution curve will never intercept the abscissa axis. High values of $k$, according to Mestdagh et al. (2004), express a rapid decrease in the organic carbon content of the soil from the surface to the subsurface layers. The surface horizons have high contents, which rapidly decrease in the deepest horizons. For these same authors, clayey, silty and silty loam soils have higher $\mathrm{k}$ values when compared to sandy soils. Ostrowska et al. (2010) found that the carbon stock in soil under coniferous forests in Poland has decreased with depth even though the thickness of the layers of the deeper horizons were two to three times higher than the superficial horizons.

The $\mathrm{F}$ test for LOFIT significance indicated that the error of the estimated values of $k$ by the numerical method is smaller than the error inherent in the values obtained by the mathematical method. It indicates that the $\mathrm{k}$ obtained by the numerical method may be the best option in the estimation of TOC and TN contents when compared to the use of $k$, estimated by the mathematical method in different land uses. In the graphical method, the F test for LOFIT significance indicated that only the estimated values of $\mathrm{k}$ for $\mathrm{TN}$ description in the soil profile are not significantly lower than the k values obtained by the mathematical method. In this case, the values of $\mathrm{k}$ for the $\mathrm{TN}$ obtained by the graphical method differ from the values obtained by the mathematical method, indicating that the coefficient $b$ of the graphical method is not a better option to estimate the rate of decay of TN content in the different land uses (Table 2).

For the statistic of the RQEM, evaluating the $\mathrm{k}$ estimated by the numerical method to the mathematical method, one can affirm that the estimated values of the decay rate $(\mathrm{k})$ are within the acceptable range $\left(\mathrm{RQME}_{95 \%}\right)$. These results are probably explained using the same exponential model applied to obtain the value of $\mathrm{k}$. In the graphical method, for the RQEM statistic, the estimated values of $k$ of the TOC and TN content, evaluating the different soil uses, are not into the acceptable confidence interval $\left(\mathrm{RQME}_{95 \%}\right)$.

However, although the statistical results of the RQME were not satisfactory, in the estimation of $k$ by the graphical method, the use of this method allowed to identify that the content of TOC and TN in the soil follows a negative exponential trend. This indicates the importance of a greater study of this model in the representation of the distribution in depth. It is worth noting this assessment for different types of soil, since 
Table 2. Lack of adjustment (LOFIT) analysis of the decay rate (k) obtained by the graphical and numerical method compared to the k obtained by the mathematical method in different uses of the soil (native grassland and Eucalyptus plantations).

\begin{tabular}{|c|c|c|c|c|c|c|c|}
\hline \multicolumn{2}{|c|}{ TOC (\%) } & \multicolumn{2}{|c|}{ TOC $\left(\mathrm{g} \mathrm{cm}^{-3}\right)$} & \multicolumn{2}{|c|}{ TN (\%) } & \multicolumn{2}{|c|}{$\mathrm{TN}\left(\mathrm{g} \mathrm{cm}^{-3}\right)$} \\
\hline \multicolumn{8}{|c|}{ Mathematical method vs. Numerical method } \\
\hline$F^{(a)}$ & $\mathbf{F}_{5 \%}$ & $\mathbf{F}^{(\mathbf{a})}$ & $\mathbf{F}_{5 \%}$ & $F^{(a)}$ & $\mathbf{F}_{5 \%}$ & $F^{(a)}$ & $\mathbf{F}_{5 \%}$ \\
\hline 0.0117 & 2.8167 & 0.0118 & 2.8167 & 0.0101 & 2.8167 & 0.0117 & 2.8167 \\
\hline RQEM $^{(\mathrm{b}) \%}$ & $\mathrm{RQEM}_{95 \%}$ & $\mathrm{RQEM}^{(\mathrm{b}) \%}$ & RQEM $_{95 \%}$ & $\mathrm{RQEM}^{(\mathrm{b}) \%}$ & RQEM $_{95 \%}$ & RQEM $^{(b) \%}$ & $\mathrm{RQEM}_{95 \%}$ \\
\hline 11.2052 & 30.6761 & 11.2187 & 30.3294 & 10.3213 & 28.0298 & 11.0711 & 28.1687 \\
\hline \multicolumn{8}{|c|}{ Mathematical method vs. Graphical method } \\
\hline $\mathbf{F}^{(\mathrm{a})}$ & $\mathbf{F}_{5 \%}$ & $\mathbf{F}^{(\mathrm{a})}$ & $F_{5 \%}$ & $F^{(a)}$ & $\mathbf{F}_{5 \%}$ & $F^{(a)}$ & $F_{5 \%}$ \\
\hline 2.3009 & 2.8167 & 1.9942 & 3.0491 & 10.4312 & 2.8167 & 11.3050 & 2.8167 \\
\hline RQEM $^{(b) \%}$ & RQEM $_{95 \%}$ & RQEM $^{(\mathrm{b}) \%}$ & RQEM $_{95 \%}$ & $\mathrm{RQEM}^{(\mathrm{b}) \%}$ & RQEM $_{95 \%}$ & RQEM $^{(\mathrm{b}) \%}$ & RQEM $_{95 \%}$ \\
\hline 156.9878 & 30.6761 & 145.6731 & 30.3294 & 331.1870 & 28.0298 & 344.1466 & 28.1687 \\
\hline
\end{tabular}

TOC: total organic carbon; TN: total nitrogen.

these soils have a textural B horizon with tendency to increase the clay content and the easy translocation of particles, elements and organic material along the profile. In coniferous forests in Poland, sand-derived soils, according to Ostrowska et al. (2010), have lower stability and more intensive translocation of organic matter, compared to clayey soils.

\subsection{Content of TOC and TN estimated from the values of $k$}

An overestimation of TOC was observed at depths greater than $0.5 \mathrm{~m}$ by the use of the graphical $\mathrm{k}$ in the Eucalyptus plantations cultivated in Santa Maria, where the Bt horizon is at a depth of 0.8 to $0.9 \mathrm{~m}$. In the Eucalyptus plantations cultivated in Manoel Viana, with a textural Bt occurring at 1 to $1.5 \mathrm{~m}$, underestimates of this content were observed greater than $0.9 \mathrm{~m}$. It is emphasized that, in the soil of Manoel Viana, when using the mathematical and numerical $\mathrm{k}$, an overestimation of the TOC occurs from down to $0.15 \mathrm{~m}$. Regarding the TN content in Eucalyptus plantations, there were more expressive overestimations in the soil of Manoel Viana when using the $\mathrm{k}$ of the mathematical and numerical method in this estimate.

For the $\mathrm{g} \mathrm{cm}^{-3}$ content, in the Eucalyptus plantations from the soil of Santa Maria, the TOC was overestimated down to $0.5 \mathrm{~m}$ when the graphical $\mathrm{k}$ was used. As for the $\mathrm{TN}$, these overestimations occurred with the mathematical and numerical $\mathrm{k}$. In the soil of Manoel
Viana, the TOC and TN contents were underestimated by the use of the graphical $k$ value, and overestimated with the mathematical and numerical $\mathrm{k}$ values (Figure 2).

These differences in the adjustments may be conditioned to the Bt textural depth and the soil texture, especially the percentage of coarse sand and the management of each site. Jobbágy \& Jackson (2000) confirm this negative exponential form of distribution in different land uses. For Eucalyptus, this form of distribution is confirmed in plantations from zero to seven years (Rufino, 2009), as well as in plantations after 10 to 13 years (Bashkin \& Binkley, 1998). In the native grassland, this form of distribution is presented by Yang et al. (2010) in Tibet and by Mikhailova et al. (2000) with 10, 12 and 50 years of and by Jobbágy \& Jackson (2000) in different land uses.

For the T-test paired (Table 3), the overestimation of the TOC and TN content is recorded by the use of $k$ obtained by the mathematical and numerical method in the native grassland and Eucalyptus plantations in Manoel Viana. These estimates may be conditioned to the percentage of fractions in the textural condition of each soil, mainly related to coarse sand and morphology, such as the depth of the Bt horizon and, finally, associated to the conditions of use and management, once this area has already received thinning interventions when compared to the soil of Santa Maria.

The values of $k$ obtained by the mathematical and numerical methods tend to overestimate the content 

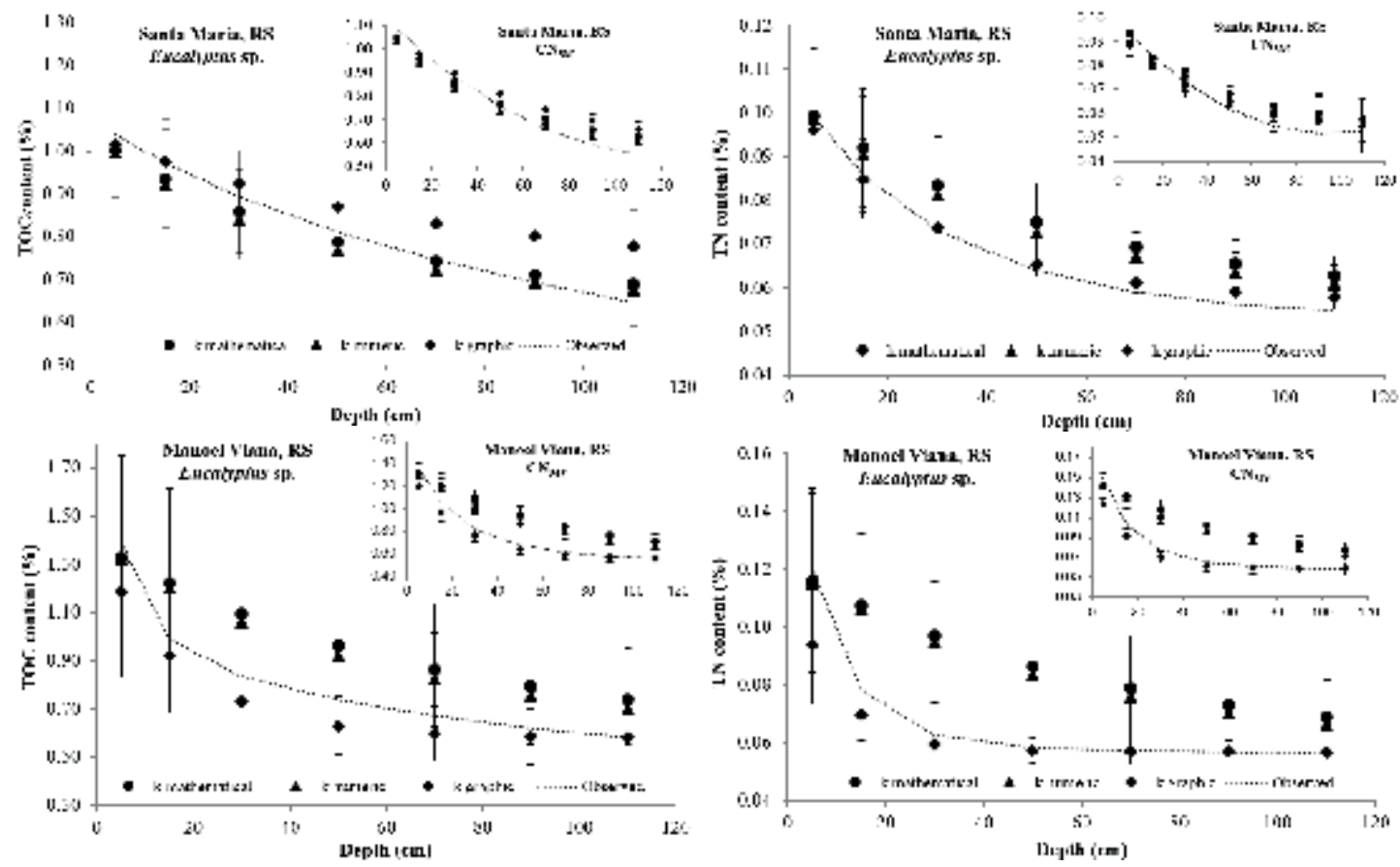

Figure 2. Average of total organic carbon (TOC) and total nitrogen (TN) content (\%) observed and estimated with $\mathrm{k}$ values for different land uses. Vertical bars represent the standard deviation of the percentage of TOC and TN estimated by depth.

Table 3. Value of $\mathrm{T}$ (P-value) of TOC and TN content $\left(\%\right.$ and $\left.\mathrm{g} \mathrm{cm}^{-3}\right)$, with dependent samples at the $5 \%$ error level, in the different land uses using the $\mathrm{k}$ obtained by the mathematical $\left(\mathrm{K}_{\text {mathematical }}\right)$, numerical $\left(\mathrm{k}_{\text {numeric }}\right)$ and graphic $\left(\mathrm{k}_{\text {graphic }}\right)$ method.

\begin{tabular}{|c|c|c|c|c|}
\hline \multirow{2}{*}{ Site } & \multirow{2}{*}{ TOC } & \multicolumn{3}{|c|}{ T (P-value) } \\
\hline & & $\mathrm{Ck}_{\text {mathematical }} \times \mathrm{C}_{\mathrm{Obs}}$ & $\mathrm{Ck}_{\text {numerical }} \times \mathrm{C}_{\text {Obs }}$ & $\mathrm{Ck}_{\text {graphic }} \times \mathrm{C}_{\mathrm{Obs}}$ \\
\hline \multirow{2}{*}{ Santa Maria } & $\%$ & $-0.621(0.5363)$ & $-3.399(0.0010)$ & $5.423(5.6492 \mathrm{E}-7)$ \\
\hline & $\mathrm{g} \mathrm{cm}^{-3}$ & $-1.282(0.2034)$ & $-4.096(9.7330 \mathrm{E}-5)$ & $5.938(6.4789 \mathrm{E}-8)$ \\
\hline \multirow{2}{*}{ Manoel Viana } & $\%$ & $6.272(1.529 \mathrm{E}-8)$ & $5.993(5.1224 \mathrm{E}-8)$ & $-4.938(4.0321 \mathrm{E}-6)$ \\
\hline & $\mathrm{g} \mathrm{cm}^{-3}$ & $5.285(9.955 \mathrm{E}-7)$ & $4.842(5.883 E-6)$ & $-5.043(2.654 \mathrm{E}-6)$ \\
\hline \multirow{2}{*}{ Site } & \multirow{2}{*}{$\mathbf{T N}$} & \multicolumn{3}{|c|}{ T (P-value) } \\
\hline & & $\mathrm{Ck}_{\text {mathematical }} \mathrm{x} \mathrm{C}_{\mathrm{Obs}}$ & $\mathrm{Ck}_{\text {numerical }} \times \mathrm{C}_{\text {obs }}$ & $\mathrm{Ck}_{\text {graphic }} \times \mathrm{C}_{\text {obs }}$ \\
\hline \multirow{2}{*}{ Santa Maria } & $\%$ & $6.581(3.9424 \mathrm{E}-9)$ & $4.874(5.1760 \mathrm{E}-6)$ & $\mathbf{0 . 8 1 9}(0.4154)$ \\
\hline & $\mathrm{g} \mathrm{cm}^{-3}$ & $5.200(1.4085 \mathrm{E}-6)$ & $2.874(0.0051)$ & $-1.163(0.2483)$ \\
\hline \multirow{2}{*}{ Manoel Viana } & $\%$ & $\mathbf{9 . 6 0 4}(4.0493 \mathrm{E}-15)$ & $9.786(1.7518 \mathrm{E}-15)$ & $-5.357(7.4151 \mathrm{E}-7)$ \\
\hline & $\mathrm{g} \mathrm{cm}^{-3}$ & $8.847(1.323 E-13)$ & $8.902(1.023 \mathrm{E}-13)$ & $-6.264(1.583 \mathrm{E}-8)$ \\
\hline
\end{tabular}

TOC: total organic carbon; TN: total nitrogen; $\mathrm{Ck}_{\text {mathemátical }}$ content estimated by the $\mathrm{k}$ value obtained by the mathematical method; $\mathrm{Ck}_{\text {numerical }}$ : content estimated by the value of $\mathrm{k}$ obtained by the numerical method; $\mathrm{Ck}_{\text {graphic }}$ : content estimated by the value of $\mathrm{k}$ obtained by the graphical method. $\mathrm{C}_{\mathrm{obs}}$ : observed content; Values in bold: estimated content differs statistically from observed content at the level of $5 \%$ error. 
of TOC and TN in the soil profile of different sites. Comparing the $\mathrm{F}_{5 \%}$ and RQEM test statistics, the use of these $\mathrm{k}$ would not be efficient in estimating the TOC and TN content in depth, suggesting the use of the graphical $\mathrm{k}$ for these locations. Therefore, this can be considered in the land uses where the value of $\mathrm{k}$ obtained by the graph method is greater than 2 to $5 \%$.

The negative exponential model can be used where the TOC and TN content in the soil profile follows this trend, however, it is important to determine the rate to each site. Mestdagh et al. (2004) point out that different values of $k$ are obtained between regions and models, generating large differences in the estimated TOC content. Therefore, any local variation affects the quality of fit in any other profile when using this negative exponential function (Minasny et al., 2006). However, the estimation of this decay rate in the profile has the advantage of being fast, but when it is used by different methods, it is perceived that the graphical method is more laborious in this estimation. In addition, in all cases it is relevant to consider the error attributed to the TOC and TN content estimated in each soil layer along the profile, depending on the model used, as well as the estimated decay rate quality.

\section{CONCLUSIONS}

The TOC and TN contents in the profile of the different soil uses present a third order negative exponential distribution pattern, according to the different methods in the representation of this dynamics. However, when choosing the method to determine this decay rate, it is advisable to evaluate the quality of this estimate since there are differences in the estimated TOC and TN content along the soil profile.

\section{SUBMISSION STATUS}

Received: 14 Feb., 2017

Accepted: 26 Oct., 2017

\section{CORRESPONDENCE TO}

\section{Charlote Wink}

Universidade Federal do Mato Grosso (UFMT), Instituto de Ciências Agrárias e Ambientais (ICAA), Av. Alexandre Ferronato, 1.200, CEP 78557-267, Sinop, MT, Brasil e-mail: charlote.wink@gmail.com

\section{REFERENCES}

Bashkin MA, Binkley D. Changes in soil carbon following afforestation in Hawaii. Ecology 1998; 79(3): 828-833. $10.2307 / 176582$

Bernoux M, Dominique A, Cerri CC, Bourennane H. Modelling vertical distribution of carbon in oxisols of the western Brazilian Amazon (Rondonia). Soil Science 1998; 163(12): 941-951. 10.1097/00010694-199812000-00004

Boddey RM, Jantalia CP, Conceição PC, Zanatta JA, Bayer $\mathrm{C}$, Mielniczuk J et al. Carbon accumulation at depth in Ferralsols under zero-till subtropical agriculture. Global Change Biology 2010; 16(2): 784-795. 10.1111/j.13652486.2009.02020.x

Carvalho JLN, Avanzi JC, Silva MLN, Mello CR, Cerri CEP. Potencial de sequestro de carbono em diferentes biomas do Brasil. Revista Brasileira de Ciência do Solo 2010;34(2):277-289. 10.1590/S0100-06832010000200001

Charnay MP, Tuis S, Coquet Y, Barriuso E. Spatial variability in 14C-herbicide degradation in surface and subsurface soils. Pest Management Science 2005; 61(9): 845-855. 10.1002/ps.1092

Elzein A, Balesdent J. Mechanistic simulation of vertical distribution of carbon concentrations and residence times in soils. Soil Science Society of America Journal 1995; 59(5): 1328-1335. 10.2136/sssaj1995.03615995005900050019x

Fontaine S, Barot S, Barré P, Bdioui N, Mary B, Rumpel C. Stability of organic carbon in deep soil layers controlled by fresh carbon supply. Nature 2007; 450(8): 277-281. 10.1038/nature06275

Gatto A, Barros NF, Novais RF, Silva IR, Leite HG, Leite FP et al. Estoques de carbono no solo e na biomassa em plantações de eucalipto. Revista Brasileira de Ciência do Solo 2010; 34(4): 1069-1079. 10.1590/S010006832010000400007

Harrison RB, Footen PW, Strahm BD. Deep soils horizons: contribution and importance to soil carbon pools and in assessing whole-ecosystem response to management and global change. Forest Science 2011; 57(1): 67-76. 10.1093/ forestscience/57.1.67

Hilinski T. Implementation of exponential depth distribution of organic carbon in the Century Model. 2001 [cited 2010 Apr. 1]. Available from: https://bit.ly/2QNjk3u

Jobbágy EG, Jackson RB. The vertical distribution of soil organic carbon and its relation to climate and vegetation. Ecological Applications 2000; 10(2): 423-436. 10.1890/1051-0761(2000)010[0423:TVDOSO]2.0.CO;2

Meersmans J, Wesemael BV, Ridder F, Molle MV. Modelling the three-dimensional spatial distribution of soil organic carbon (SOC) at the regional scale (Flandres, Belgium). Geoderma 2009; 152(1-2): 43-52. 10.1016/j. geoderma.2009.05.015 
Mestdagh I, Lootens P, Cleemput OV, Carlier L. Soil organic carbon stocks in Flemish grasslands: how accurate are they? Grass and Forage Science 2004; 59(4): 310-317. 10.1111/j.1365-2494.2004.00432.x

Mikhailova EA, Bryant RB, Vassenev II, Schwager SJ, Post CJ. Cultivation effects on soil carbon and nitrogen contents at depth in the Russian Chernozem. Soil Science Society American Journal 2000; 64(2): 738-745. 10.2136/ sssaj2000.642738x

Minasny B, Mcbratnec AB, Santos MLM, Guyon B. Predicting and digital mapping of soil carbon storage in the Lower Namoi Valley. Soil Research 2006; 44(3): 233-244. 10.1071/SR05136

Moreno JA. Clima do Rio Grande do Sul. Porto Alegre: Secretaria da Agricultura; 1961.

Nakane K, Shinozaki K. A mathematical model of the behavior and vertical distribution of organic carbon in forest soils. Japanese Journal of Ecology 1978; 28(2): 111-122. 10.18960/seitai.28.2_111

Ostrowska A, Porębska G, Kanafa M. Carbon accumulation and distribution in profiles of forest soils. Polish Journal of Environment Studies 2010; 19(6): 1307-1315.

Rosa SF. Propriedades físicas e químicas de um solo arenoso sob o cultivo de Eucalyptus spp [thesis]. Santa Maria: Universidade Federal de Santa Maria; 2010.

Rosenbloom N. A hillslope evolution model for the croupled prediction of soil texture and ecosystem dynamics [thesis]. Boulder: University of Colorado; 1997.

Rosenbloom NA, Harden JW, Neff JC, Schimel DS. Geomorphic control of landscape carbon accumulation. Journal of Geophysical Research 2006; 111: 1-10. 10.1029/2005JG000077

Rufino AMM. Estoque de carbono em solos sob plantios de eucalipto e fragmento de cerrado [thesis]. Botucatu: Universidade Estadual Paulista; 2009.

Rumpel C, Kögel-Knabner I. Deep soil organic matter: a key but poorly understood component of terrestrial C cycle. Plant and Soil 2011; 338(1-2): 143-158. 10.1007/ s11104-010-0391-5
Santruckova H, Kastovska E, Kolzov D, Kurbatova ML, Shibistova O, Tatarinov F et al. Vertical and horizontal variation of carbon pools and fluxes in soil profile of wet southern taiga in European Russia. Boreal Environment Research 2010; 15(3): 357-369.

Schumacher MV, Witschoreck R. Inventário de carbono em povoamentos de Eucalyptus ssp. nas propriedades fumageiras do sul do Brasil: um estudo de caso. In: Sanquetta CR, Balbinot R, Zilliotto MA, editors. Fixação de carbono: atualidades, projetos e pesquisas. Curitiba: UFPR; 2004. p. 111-124.

Smith P, Smith JU, Powlson DS, McGill WB, Arah JRM, Chertov OG et al. A comparison of the performance of nine soil organic matter models using datasets from seven long-term experiments. Geoderma 1997; 81(1-2): 153-225. 10.1016/S0016-7061(97)00087-6

Soil Survey Staff. Soil taxonomy: a basic system of soil classification for making and interpreting soil surveys. 2nd ed. Washington: Natural Resources Conservation Service; 1999.

Torn MS, Trumbore SE, Chadwick OA, Vitousek PM, Hendricks DM. Mineral control of soil organic carbon storage and turnover. Nature 1997; 389(11): 170-173. $10.1038 / 38260$

Wang Y, Li Y, Ye X, Chu Y, Wang X. Profile storage of organic/inorganic carbon in soil: from forest to desert. Science of the Total Environment 2010; 408(8): 1925-1931. 10.1016/j.scitotenv.2010.01.015

Wink C. Estoque de carbono em plantações de Eucalyptus sp. implantados em campo nativo [thesis]. Santa Maria: Universidade Federal de Santa Maria; 2009.

Wink C. Dinâmica do carbono e nitrogênio em Argissolos com plantações de Eucalyptus sp [dissertation]. Santa Maria: Universidade Federal de Santa Maria; 2013.

Yang YH, Fang JY, Guo DL, Ji CJ, Ma WH. Vertical patterns of soil carbon, nitrogen and carbon: nitrogen stoichiometry in Tibetan grasslands. Biogeosciences Discuss 2010; 7(1): 1-24. 10.5194/bgd-7-1-2010 